\title{
Microbiological quality and HACCP concept in the production of "Nono" in a farm settlement in Minna, Niger state, Nigeria
}

\author{
Omotosho, A. ${ }^{1}$, Abdullahi, I. $\mathrm{O}^{2^{\star}}$ and Damisa, D \\ ${ }^{1}$ Department of Microbiology, Federal university of Technology, Minna, Nigeria. \\ ${ }^{2}$ Department of Microbiology, Ahmadu Bello University, Zaria, Nigeria.
}

Accepted 10 May, 2013

\begin{abstract}
The hazard analysis critical control point (HACCP) procedures were adopted to identify hazards and critical control points in the production of Nono in a farm settlement in Minna, Nigeria. The swabs of cow udder, samples of raw milk, handlers palms, equipment for processing (calabash, sieves and spoons/laddle), the fermented milk (Nono), and the water used in the production were microbiologically analysed using standard microbiological methods. The results from these sources indicated high counts above the specifications. The count for the water (from well and stream) used by the producers showed aerobic plate count to be between $9.0 \times 10^{2}$ and $3.0 \times 10^{4} \mathrm{cfu} / \mathrm{ml}$ and the MPN values for the water ranged from 15 to $2.1 \times 10^{2}$. Various pathogenic organisms were isolated. The sources of water in the processing are a major source of contamination of the Nono with pathogenic organisms which if not controlled could pose a serious threat to the consumers. The critical control point of the process was the fermentation stage which is very critical to the whole process and loss of control here will affect the final quality of the product.
\end{abstract}

Key words: Hazard analysis critical control point (HACCP), Nono, microbiological quality.

\section{INTRODUCTION}

'Nono' is the Hausa name for fermented milk which is sold along with butter, (mai shanu) a by- product of its production. It is a crude cultured whole milk whose fermentation may be brought about by a number of bacterial species from various sources that contaminate the fresh milk (Atanda and Ikenebomeh, 1990). 'Nono' is locally produced in homes, especially in villages where shelf-life and safety of the product is not considered. 'Nono' is however sold to all interested people as food. 'Nono' is produced from non-pasteurized cow milk collected in a calabash and allowed to ferment naturally for $24 \mathrm{~h}$ (Eka and Ohaba, 1977; Olasupo et al., 1996). A tool with which food industries all over the world are adapting to aid in the production of safe and wholesome foods is the Hazard Analysis Critical Control Point (HACCP) system (Sanni, 1997, Solomon 2001).

HACCP has been recognized internationally as a logical tool for adapting traditional inspection methods to a modern, science-based, food safety system. Based on risk assessment, HACCP plans allow both industry and government to allocate their resources efficiently in establishing and auditing safe food production practices. Hazard analysis is the procedure used to identify significant potential hazards and conditions leading to the presence in foods. It evaluates the likelihood of the hazard being present and the severity of an adverse 
health effect when it occurs in order to determine if it is significant for food safety. When significant hazards and conditions leading to their presence in foods are identified, measures for their control have to be established (Schothorst, 2004). A tool with which food industries all over the world are adapting to aid in the production of safe and wholesome foods is the HACCP system (Sanni, 1997; Solomon 2001; and McDonough, 2002).

'Nono' is one of the popular foods consumed in the Northern part of Nigeria; it is a product from raw milk obtained from cows, sheep or goats that is hardly pasteurized. This raw unpasteurized milk product can carry dangerous bacteria such as Salmonella spp, Escherichia coli, and Listeria spp, which are responsible for causing food borne illnesses. Bacteria can increase in raw milk due to poor milking methods, inadequate cleaning of milking equipment, poor cooling, and, in some cases, as a result of mastitis (Annonymous, 2009). These harmful bacteria can seriously affect the health of anyone who drinks raw or locally processed milk. It is therefore necessary to evaluate and establish the safety of 'Nono' as product from raw milk (FAO, 1997). The present study aims to determine microbiological hazards associated with 'Nono' production and their possible controls. Following HACCP concept Thus, the study will identify the critical control points (CCP) in the production chain in the village, isolate, identify, and characterize microorganisms found in raw milk from the cow, equipment, handlers' hand and finished product ('Nono') and evaluate the microbiological quality of water used during 'Nono' production.

\section{MATERIALS AND METHODS}

\section{Sample collection}

Twenty (20) samples each of hand swabs, cow udder, raw milk, 'Nono' and swabs of spoons, sieves and calabash were collected following the processing steps in the HACCP determination at various times. These samples were transported to the Microbiology Department Laboratory, Federal University of Technology (FUT( Minna, Nigeria, for analysis. The analysis was carried out within 2 to $3 \mathrm{~h}$ of sample collection.

\section{Microbiological tests}

\section{Total viable counts}

Aliquots of the serially diluted samples were aseptically transferred in duplicates directly onto the plates. The plates were incubated at $37^{\circ} \mathrm{C}$ for $24-48 \mathrm{~h}$. Colonies which developed on the plates were counted using the colony counter (model 6399/Stuart Scientific Co. Ltd., Great Britain) and expressed as colony forming units per millimeter $(\mathrm{cfu} / \mathrm{ml})$ of samples. The colonies differing in size, shape and colour were selected from the different plates on nutrient agar and subcultured repeatedly to obtain pure isolates. The pure isolates were maintained on agar slants for further characterization and identification.

\section{Total coliform counts}

Serially diluted $0.1 \mathrm{ml}$ of samples were aseptically plated on
MacConkey agar for the enumeration of total coliform counts. The plates were incubated at $37^{\circ} \mathrm{C}$ for $24-48 \mathrm{~h}$. Colonies which developed on the plates were counted using the colony counter (model 6399/Stuart scientific Co. Ltd, Great Britain) and expressed as colony forming units per milliliter (cfu/ml) of samples.

\section{Faecal coliforms (E.coli) counts in milk and water samples}

The most probable number (MPN) technique was used as described by Fawole et al. (2002); and Bakare et al. (2003). This is the three tube procedure using lactose broth to detect the organism and determine the MPN of coliforms bacilli using the McCrady Table (Standard Methods for the Examination of Water and Water (SMEWW), (1999). The technique consists of three steps, these include:

\section{Presumptive test}

Three tubes containing $0.1 \mathrm{ml}, 1 \mathrm{ml}$, and $10 \mathrm{ml}$ of each water sample was used to inoculate the lactose broth in triplicates. The tubes were incubated at $37^{\circ} \mathrm{C}$ for 48 hours. For the detection of faecal coliforms, production of acid and gas was taken as positive indication and confirmed the presence of the organism (D'Auriac et al., 2000).

\section{Confirmed test}

Tubes showing positive results from the presumptive test were used to inoculate MacConkey broth and incubated at $37^{\circ} \mathrm{C}$ for $48 \mathrm{~h}$. Gas production in the tubes confirmed the presence of $E$. coli and the tubes were used to determine the MPN value of the faecal coliforms using the McCrady Table.

\section{Completed test}

Tubes with gas production in the confirmed test were used to streak on eosin methylene blue (EMB) agar and incubated at $44.5^{\circ} \mathrm{C}$ for $24-48 \mathrm{~h}$ (Prescott et al., 2008). Colonies which developed on EMB was identified as $E$. coli on the completed test.

\section{Fungal counts}

Serially diluted samples of 'Nono', raw milk, swabs of cow udder, handlers palms and utensils used during 'Nono' processing were inoculated into Petri dishes $(1 \mathrm{ml})$ and molten SDA was poured and allowed to solidify before incubating at room temperature for 48 to 96 hours. The colonies that developed in the plates were counted and recorded as the colony- forming unit per millilitre (cfu/ml). Series of sub culturing were made for all the counts to obtain pure culture isolates. Each isolate was grown on a nutrient agar slant and stored for further use.

\section{RESULTS}

\section{Determination of CCP}

The critical control point was determined using the critical control point decision tree (Figure 1) as developed by the Codex Alimmentarius Committee on Food Hygiene (CODEX, 1993) and modified by Dillon and Griffith (1995). The identified critical control point (CCP) in 'Nono' production is as shown in Figure 1. After milking from cow's udder, the physical hazards are taken care of by 


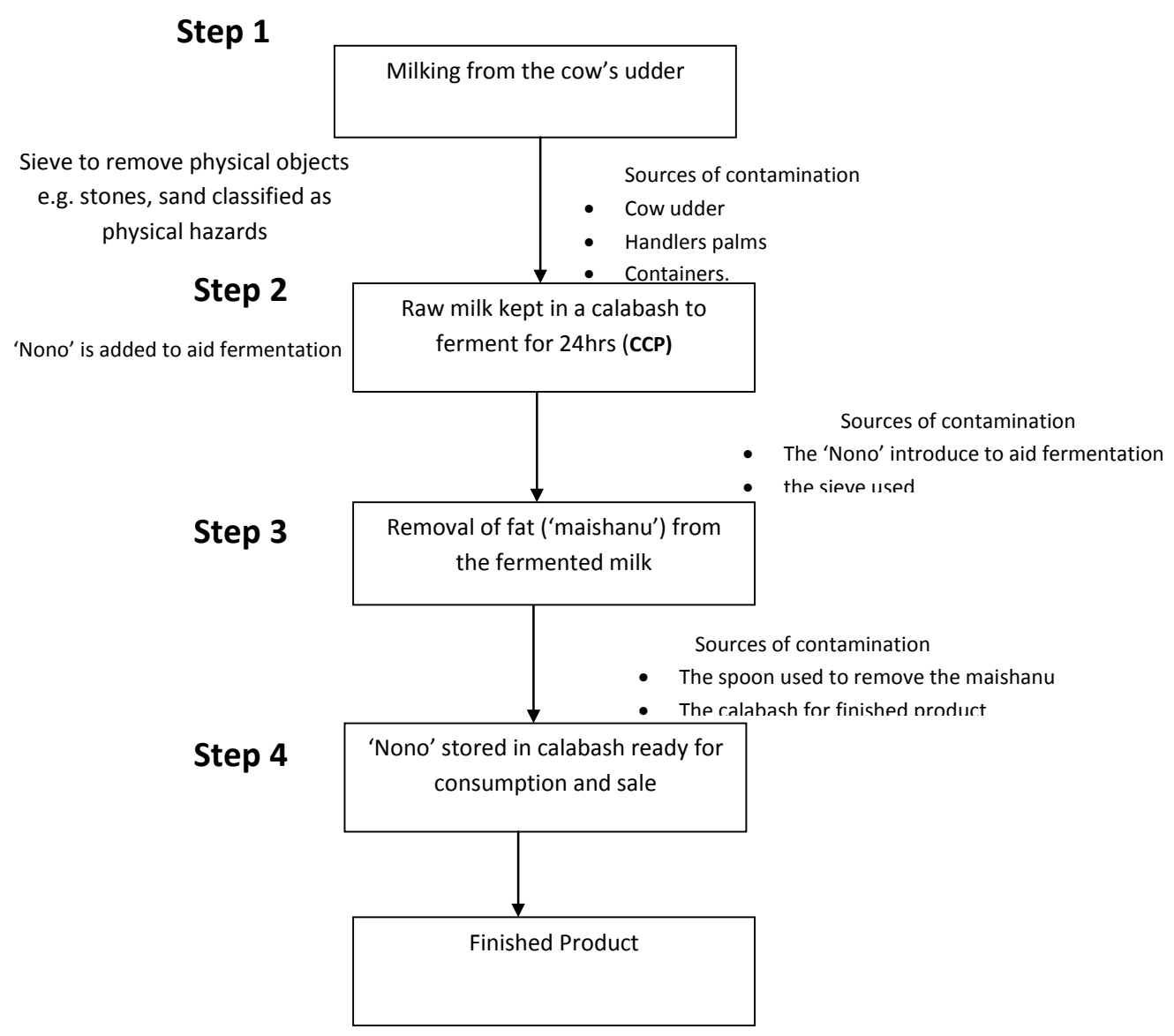

Figure 1. 'Nono' production chart with identified critical points.

sieving the raw milk to remove for example, stones, dry leaves, insects and sand. During fermentation, the acid produced reduces the growth of bacteria but may favour the growth of fungi.

\section{Microbiological hazard analysis of 'Nono' processing}

\section{Total viable counts during 'Nono' processing}

The total viable count of the various items in 'Nono' processing is presented in Table 1. The total viable counts recorded on the handlers palms before milking ranged from $3.0 \times 10^{4}-1.3 \times 10^{4} \mathrm{cfu} / \mathrm{ml}$, calabash and other production utensils ranged from $2.1 \times 10^{4}-3.4 \times 10^{4} \mathrm{cfu} / \mathrm{ml}$, cow udder before and after milking ranged from $6.0 \times$ $10^{3}-1.4 \times 10^{4} \mathrm{cfu} / \mathrm{ml}$, the raw milk ranged from $1.2 \times 10^{5}$ $-3.5 \times 10^{5} \mathrm{cfu} / \mathrm{ml}$, handlers palms after milking ranged from $4.0 \times 10^{4}-1.6 \times 10^{5} \mathrm{cfu} / \mathrm{ml}$, the 'Nono' sample counts ranged from $1.7 \times 10^{5}-7.0 \times 10^{5} \mathrm{cfu} / \mathrm{ml}$.

\section{Faecal coliform count}

The faecal coliform counts for the process showed that the highest mean count of $6.7 \times 10^{4} \mathrm{Cfu} / \mathrm{ml}$ was obtained in the finished product while the least count was obtained in the cloth sieves used (Table 2)

\section{Fungal Counts}

The fungal count during the processing (Table 4) showed a mean count of $3.9 \times 103$ with a range count of $2.0 \times 10^{3}$ to $5.7 \times 10^{3} \mathrm{cfu} / \mathrm{ml}$ for the final product. The various processing utensils involved recorded various counts

\section{Microbiological analysis of water used during 'Nono' processing}

The microbiological analysis of water used for 'Nono' preparation result is as presented in Table 5. The most probable number ranged from $15-210 \mathrm{MPN} / 100 \mathrm{ml}$. The lowest most probable number was $15 \mathrm{MPN} / 100 \mathrm{ml}$ of samples from stream water while the highest was 210 MPN $/ 100 \mathrm{ml}$ of sample from well water. The bacterial load ranged from $9.0 \times 10^{2}-3.0 \times 10^{4} \mathrm{cfu} / \mathrm{ml}$.

\section{DISCUSSION}

The critical control point of 'Nono' production (Figure 1) was essentially at the fermentation stage which if not well monitored the product quality will be affected. 'Nono' may become sour and acidic if fermentation time exceed $72 \mathrm{~h}$. Also, the sources of contaminations such as the Nono 
Table 1. Total viable counts during 'Nono' processing.

\begin{tabular}{lcc}
\hline Sample & Range of counts (cfu/ml) & Mean count (cfu/ml) \\
\hline Handler's Palms before Milking & $3.0 \times 10^{4}-1.3 \times 10^{4}$ & $2.1 \times 10^{4^{*}}$ \\
Calabash & $6.0 \times 10^{4}-7.5 \times 10^{4}$ & $6.2 \times 10^{4^{*}}$ \\
Sieves & $2.1 \times 10^{4}-3.4 \times 10^{4}$ & $2.7 \times 10^{4^{*}}$ \\
Spoon & $3.0 \times 10^{3}-1.0 \times 10^{4}$ & $2.0 \times 10^{4^{*}}$ \\
Cow udder before milking & $6.0 \times 10^{3}-1.4 \times 10^{4}$ & $3.7 \times 10^{4}$ \\
Raw milk & $1.2 \times 10^{5}-3.5 \times 10^{5}$ & $2.3 \times 10^{5}$ \\
Cow udder after milking & $2.7 \times 10^{4}-5.3 \times 10^{4}$ & $4.0 \times 10^{4}$ \\
Handler's palms after milking & $4.0 \times 10^{4}-1.6 \times 10^{5}$ & $2.7 \times 10^{4^{*}}$ \\
Final product (Nono) & $1.7 \times 10^{5}-7.0 \times 10^{5}$ & $4.2 \times 10^{4}$ \\
\hline
\end{tabular}

Values are the mean of 20 samples. Counts are in $\mathrm{cfu} / \mathrm{sq} \mathrm{cm}$.

Table 2. Faecal coliform counts during 'Nono' processing.

\begin{tabular}{lcc}
\hline Sample & Range of counts (cfu/ml) & Mean count (cfu/ml) \\
\hline Handler's palms before milking & $4.2 \times 10^{4}-5.0 \times 10^{4}$ & $4.6 \times 10^{4^{*}}$ \\
Calabash & $3.0 \times 10^{3}-6.0 \times 10^{3}$ & $5.7 \times 10^{3^{*}}$ \\
Sieves & $2.0 \times 10^{3}-2.5 \times 10^{3}$ & $3.3 \times 10^{3^{*}}$ \\
Spoon & $1.3 \times 10^{4}-2.5 \times 10^{4}$ & $1.9 \times 10^{4^{*}}$ \\
Cow udder before milking & $3.0 \times 10^{3}-5.3 \times 10^{3}$ & $5.6 \times 10^{3}$ \\
Raw milk & $1.5 \times 10^{4}-6.8 \times 10^{4}$ & $4.2 \times 10^{4}$ \\
Cow udder after milking & $3.5 \times 10^{4}-5.8 \times 10^{4}$ & $4.6 \times 10^{4}$ \\
Handler's palms after milking & $3.7 \times 10^{4}-4.3 \times 10^{4}$ & $3.8 \times 10^{4}$ \\
Final product (Nono) & $6.0 \times 10^{4}-7.5 \times 10^{4}$ & $6.7 \times 10^{4}$ \\
\hline
\end{tabular}

Values are the mean of 20 samples. Counts are in $\mathrm{cfu} / \mathrm{sq} \mathrm{cm}$.

introduced as starter culture, the cow udder which was mostly heavily contaminated, the utensils which were also contaminated by the water used in cleaning them and the water used in processing 'Nono' should be controlled in order to reduce the microbial load to acceptable levels.

The total viable count and faecal coliform counts (Tables 1 and 2) are significant as the selected specification for the microbiological assessment of foods states that the total viable count should not exceed $10^{2} \mathrm{cfu} / \mathrm{g}$ or $\mathrm{ml}$ (Owanumi, 1997). HelgreenandReinemann (2003) reported that the total viable count of raw milk should not be more than $1.0 \times 10^{4} \mathrm{cfu} / \mathrm{ml}$. The total viable counts of both raw milk and Nono were more than the limit or permissible level in milk. The source of contamination may be through themilkingutensils, environmentorhandlers(Ergonul,2007).

Salmonella was detected in the final product and cow udder samples (Table 3). Salmonella is said to be an important pathogen of worldwide significance and about 3 $-6 \%$ of raw milk always indicated salmonella presence. The presence of Salmonella in this investigation could probably be due to acute episode of salmonellosis or contamination via faecal matter, dust and environmental sources as reported by Poppe, 2011.
The bacteria isolated from Nono (fermented milk) included species of Bacillus, Salmonella, Staphylococcus aureus, Streptococccus faecalis, Klebsiella pneumoniae, Escherichia coli, Lactobacillus acidophilus and Pseudomonas aeruginosa. Staphylococcus aureus are harboured by either asymptomatic carriers or can be spread by hands, expelled from the respiratory tract or transported in or on animate and inanimate objects (Prescott et al., 1999). S. aureus is a normal flora of skin, nose and throat (Pelczar et al., 2003). Its presence in 'Nono' indicates contact between 'Nono' and skin or discharges from the nose and mouth of food handlers. Its high occurrence in Nono may be due to poor hygiene practices of the food handlers during milking. The raw (milk) usually had contact with environment after milking as the raw milk is normally exposed to natural air.

The result of high Staphylococcus count agrees with Pelczar et al. (2003) who reported that human carriers are responsible for contaminating food with an enterotoxin producing strain of $S$. aureus. These findings also agree with Krishimoto et al. (2004) who reported that the presence of $S$. aureus from the same ribogroup detected on the hands of a study participant was found on a spoon. S. aureus was isolated from all processing 
Table 3. Salmonella Shigella counts during 'Nono' processing.

\begin{tabular}{|c|c|c|}
\hline Sample & Range of Salmonella/shigella counts (cfu/ml) & Mean count (cfu/ml) \\
\hline Handler's palm before milking & Nil & Nil \\
\hline Calabash & $1.6 \times 10^{3}-3.2 \times 10^{4}$ & $2.4 \times 10^{3^{*}}$ \\
\hline Sieves & Nil & Nil \\
\hline Spoon & Nil & Nil \\
\hline Cow udder before milking & Nil $-1.3 \times 10^{3}$ & $1.3 \times 10^{3}$ \\
\hline Raw milk & Nil & Nil \\
\hline Cow udder after milking & Nil & Nil \\
\hline Handler's palms after milking & Nil & Nil \\
\hline Final product (Nono) & Nil $-2.0 \times 10^{3}$ & $1.2 \times 10^{3}$ \\
\hline
\end{tabular}

Values are the mean of 20 samples. Counts are in cfu/sq cm.

Table 4. Fungal counts of 'Nono' sample.

\begin{tabular}{lcc}
\hline Sample & Range of fungal counts (cfu/ml) & Mean count (cfu/ml) \\
\hline Handler's palms before milking & $3.0 \times 10^{2}-6.3 \times 10^{3}$ & $4.7 \times 10^{3^{*}}$ \\
Calabash & $4.2 \times 10^{3}-5.6 \times 10^{3}$ & $4.9 \times 10^{3^{*}}$ \\
Sieves & $3.5 \times 10^{3}-6.7 \times 10^{3}$ & $5.1 \times 10^{3^{*}}$ \\
Spoon & $1.0 \times 10^{2}-2.0 \times 10^{3}$ & $1.5 \times 10^{3^{*}}$ \\
Cow udder before milking & $2.0 \times 10^{2}-3.6 \times 10^{3}$ & $2.8 \times 10^{3}$ \\
Raw milk & $8.0 \times 10^{2}-3.4 \times 10^{3}$ & $5.7 \times 10^{3}$ \\
Cow udder after milking & $6.0 \times 10^{2}-2.4 \times 10^{3}$ & $4.2 \times 10^{3}$ \\
Handler's palms after milking & $5.0 \times 10^{2}-3.2 \times 10^{3}$ & $4.0 \times 10^{3}$ \\
Final product (Nono) & $2.0 \times 10^{3}-5.7 \times 10^{3}$ & $3.9 \times 10^{3}$ \\
\hline
\end{tabular}

Values are the mean of 20 samples. Counts are in $\mathrm{cfu} / \mathrm{sq} \mathrm{cm}$.

Table 5. Most probable number (MPN) determination of water samples used in 'Nono' preparation.

\begin{tabular}{cccc}
\hline Water sample & Readings & MPN /100ml & Remarks \\
\hline S 100 & $3: 2: 2$ & 210 & Not potable \\
W 100 & $2: 2: 1$ & 28 &, \\
S 200 & $3: 1: 1$ & 75 &, \\
W200 & $2: 1: 0$ & 15 &, \\
S300 & $3: 0: 2$ & 64 &, \\
W300 & $2: 1: 1$ & 20 &, \\
S400 & $3: 1: 0$ & 43 &, \\
W400 & $3: 0: 2$ & 64 &, \\
S500 & $2: 1: 0$ & 15 &, \\
W500 & $3: 0: 2$ & 64 &, \\
S600 & $3: 2: 0$ & 93 &, \\
W600 & $3: 0: 1$ & 39 &, \\
\hline
\end{tabular}

S, Stream water; W, well water.

stages of Nono. This agrees with the findings of Sariano et al. (2004) who also reported the isolation of $S$. aureus from some fermented foods.

McKane et al.(2006) suggested that emergence of Gram positive organisms in fermented milk is indicative of improper food handling while the isolation of gram negative bacteria could be due to environmental influences.

Potable water has been the problem of developing countries especially African countries because there is no 
access to safe and potable water. The water used in the processing of 'nono' in this settlement is not potable (Table 5). The organisms such as E. coli and Salmonella typhi should not be isolated in any potable water because they are used as indicator organisms (WHO, 2008). The coliform counts in the water used for 'Nono' production ranged between $9.0 \times 10^{2}$ and $3.0 \times 10^{4} \mathrm{cfu} / \mathrm{ml}$ (see Table 2). These counts are above the normal allowable standard in potable water (Barell et al., 2000). According to Dinsmore (2008), the udder coliform count should not be more than $30 \mathrm{cfu} / \mathrm{ml}$. The coliform count of udder before and after milking was more than $30 \mathrm{cfu} / \mathrm{ml}$ which was $3.0 \times 10^{3}-5.8 \times 10^{4} \mathrm{cfu} / \mathrm{ml}$. This showed that there is heavy contamination because most animals or cows rest on their dung and mud (dirty environment), the teat and udder are easily contaminated.

The fungal counts showed relatively low count with the highest count in the raw milk, this is not unexpected as the milking is done in dusty environment and these might have been contaminated through the spores in the dust and air

'Nono' as presently produced in this community may be a source of pathogens to consumers if the health officials do not wake up to their responsibility.

\section{REFERENCES}

Atanda OO, Ikenebomeh MJ (1990). Microbiological quality of Nono. World J. Microbiol. Biotechnol. 7:155 - 191.

Bakare AA, Lateef A, Amuda OS, Afolabi RO (2003). The aquatic toxicity and characterization of chemical and microbiological constituents of water samples from Oba River, Odo - Oba, Nigeria. Asian J. Microbiol. Biotechnol. Environ. Sci. 5:11 - 17.

CODEX (1993). CODEX Alimentarius Commission: Codex Committee on Food Hygiene. Guidline for the application of hazard analysis critical control point (HACCP) system. (www.codexalimentarius.net).

D'Auriac MBA, Roberts H, Sham T, Sirevag R, Hermansen LF, Berg JD (2000). Field evaluation of a semi - automated method for rapid and simple analysis of recreational water microbiological quality. Appl. Environ. Microbiol. 66:4401 - 4407.

Dinsmore P (2008). Udder Health/Milk Quality J-5 Vaccine for Prevention of Coliform Mastitis: Part 1. Vaccine Development. pp.15 $-20$.

Eka OU, Ohaba JA (1977). Microbiological examination of Fulani milk (Nono) and butter (manshanu). Niger. J. Sci. 11: 113-122.

Ergonul B (2007). Critical Control Points on the Manufacturing Line of Otlu (Herby) Cheese. Internet J. Food Safe. 9:22-25

Fawole OO, Lateef A, Amaefuna M (2002). Microbiological examination of drinking water in Ogbomoso metropolis, Southwest Nigeria. Sci. Focus 1:16-20.

Food and Agricultural Organisation FAO (1997). Food and Nutrition Paper 14/4. Manual for Food Quality Control (Microbiological Analysis). Food and Agricultural Organization, Rome.

Helgreen JM, Reinemann DJ (2003). Survey of Milk Quality on United States Dairy Farms Utilizing Automatic Milking Systems. The Society for Engineering in Agricultural, Food and Biological System. 2003 ASAE Annual International Meeting: 2-18.
Krishimoto M, Hioki Y, Okano T, Konuma H, Takamizawa Kowsikowski, F, Mistry V (2004). Cheese and Fermented Milk Foods, 3rd ed, vol. I. F. V. Kowsikowski, L.L.C., Westport, Conn. pp. 23.

McDonough JE (2002). Proactive hazards analysis and health care policy www.milbank.org/reports/proactive/sec7 retrieved june 2010.

McKane L, Gomer C, Kandel J (2006). Microbiology: Essentials and Application 4th (edn), McGraw - Hill, New York. pp.736 - 764.

Olasupo NA, Akinsanya SM, Oladele OF, Azeez MK (1996). Evaluation of nisin for the preservation of Nono, a Nigerian fermented milk product. J. Food Process. Preserv. 20: 71-78.

Owanumi GO (1997). Microbiological Quality Control of sterile and non sterile pharmaceuticals and food products. Department of pharmaceutical chemistry. University of Ibadan Press. 12:146 - 157.

Pelczar MJ, Chan ECS, Krieg WR (2003). Microbiology: Concepts and Applications. McGraw - Hill Inc, New York. pp. 680-708.

Poppe C (2011). Encyclopaedia of Diary Science, Second edition, pp 93-96.

Prescott LM, Harley JP, Klein DA (2008). Microbiology. $4^{\text {th }}$ (edn). McGraw Hill Inc. New York. pp. $907-928$.

Sanni L (1997). Quality Assurance System in the Food Industry, Jedidiah Publishers, Abeokuta. pp. 17-30.

Sariano JM, Blesa J, Rico H, Motto JO, Maries J (2004). Incidence of Staphylococcus aureus in Meals from Cafeteria. J. Food Safe. 22:67 $-140$.

Schothorst M (2004). A simple guide to understanding and applyinghazard analysis critical control point concept, $3^{\text {rd }}$ edition. New York: Scribner. pp. $20-100$.

Solomon HM (2001). Ensuring quality assurance development in the fast food industries. Invited paper presented at the $25^{\text {th }}$ Annual Conference/Anniversary and general meeting of NIFST 17 November 2001.

Standard, Methods for the Examination of Water and Wastewater (SMEWW) (1999). 18th edition Green Berry, A. E., Classeri, L. S. and Eaton, A. O.eds. American Public Health Association, Washington, D. C.69.

World Health Organization, WHO (2008). Burden of disease and cost effectiveness estimates. Available online at: www.who.int/water_sanitation health/diseases/burden/en/index.html 